UDK $577.1: 61$

ISSN 1452-8258

J Med Biochem 39: 444-451, 2020

\title{
SOLUBLE PROGRAMMED DEATH-1 (SPD-1) AND PROGRAMMED DEATH LIGAND 1 (SPD-L1) AS POTENTIAL BIOMARKERS FOR THE DIAGNOSIS AND PROGNOSIS OF GLIOMA PATIENTS
}

\author{
RASTVORLIVI PROGRAMIRANI SMRTNI LIGAND 1 (SPD-L1) \\ I PROGRAMIRANI SMRTNI LIGAND 1 (SPD-1) KAO POTENCIJALNI BIOMARKERI \\ ZA DIJAGNOZU I PROGNOZU KOD PACIJENATA SA GLIOMOM
}

\author{
Shujun Liu1,2, Yadi Zhu1,2, Chenxi Zhang1,2, Jiajia Liu1,2, Hong Lv1,2, \\ Guojun Zhang ${ }^{1,2}$, Xixiong Kang 1,2,3
}

\author{
${ }^{1}$ Laboratory Diagnosis Center, Beijing Tiantan Hospital, Capital Medical University, Beijing 100070, China \\ ${ }^{2}$ Beijing Engineering Research Center of Immunological Reagents and Clinical Research, Beijing 100070, China \\ 3 Lab of Biological Science and Medical Engineering, Beihang University, Beijing 100191, China
}

\begin{abstract}
Summary
Background: This study aimed at investigating the feasibility of testing for soluble programmed death-1 (sPD-1) and soluble programmed death ligand 1 (sPD-L1) in serum samples of glioma patients and to evaluate the diagnostic and prognostic value of these two soluble molecules.

Methods: Serum samples collected from 70 glioma patients before surgery were designated as the pre-operative (Pre) group, samples obtained from 90 post-surgery glioblastoma patients were designated as the Post group, and samples from 20 healthy volunteers were used as controls. Peripheral blood SPD-1 and SPD-L1 levels were detected by using ELISA kits and compared among the groups. The associations of these soluble molecule levels with clinicopathological variables and tumour progression were investigated.

Results: Among the three groups, the Pre group had the highest sPD-1 levels, whereas the median sPD-L1 level was significantly lower in the Post group than in the other two groups. The area under the curve (AUC) of sPD-1 (0.762) for diagnosis was similar to that of sPD-L1 (0.718). Higher serum levels of sPD-1 and sPD-L1 were present in samples of patients with more advanced brain tumours. KaplanMeier analysis showed that higher serum levels of sPD-1
\end{abstract}

\section{Kratak sadržaj}

Uvod: Ovo istraživanje imalo je za cilj da ispita mogu nost testiranja rastvorljivog programiranog smrtnog-1 (sPD-1) i rastvorljivog programiranog smrtnog liganda 1 (sPD-L1) u uzorcima seruma kod pacijenata sa gliomom i da proceni dijagnostičku i prognostičku vrednost ova dva rastvorljiva molekula.

Metode: Uzorci seruma uzeti od 70 pacijenata sa gliomom pre operacije označeni su kao preoperativna Pre-grupa, a uzorci dobijeni od 90 pacijenata sa glioblastomom posle operacije su označeni kao Post-grupa, dok su uzorci 20 zdravih dobrovoljaca korišćeni kao kontrolna grupa. Nivoi sPD-1 periferne krvi i sPD-L1 su detektovani korišćenjem ELISA kompleta i upore eni su izme u grupa. Ispitivana je povezanost ovih nivoa rastvorljivih molekula sa kliničkopatološkim varijablama i napredovanjem tumora.

Rezultati: Od tri grupe, Pre-grupa je imala najviši nivo sPD1, dok je srednji nivo sPD-L1 značajno niži u Post-grupi nego $u$ ostale dve grupe. Područje ispod krive (AUC) sPD$1(0,762)$ za dijagnozu bilo je slično kao kod sPD-L1 $(0,718)$. Viši serumski nivoi sPD-1 i sPD-L1 su bili prisutni u uzorcima pacijenata sa tumorom mozga u uznapredovalom stadijumu. Kaplan-Majerova analiza je pokazala da viši nivoi sPD-1 u serumu $(>11,14 \mathrm{pg} / \mathrm{mL})$ i sPD-L1 $(>63,03$

Address for correspondence:

Xixiong Kang

Beijing Tiantan Hospital, 119 Nansihuanxilu

Fengtai District, Beijing, China

Phone: +86 01059976881 , Fax: +86 01059976881

e-mail: kangxxtt@sina.com 
(>11.14 pg/mL) and sPD-L1 (>63.03 pg/mL) might predict shorter progression-free survival times of glioma patients.

Conclusions: This study showed that sPD-1 and sPD-L1 might be promising predictive biomarkers for the diagnosis and prognosis of glioma patients.

Keywords: soluble programmed death-1, soluble programmed death ligand 1, glioma, biomarkers, prognosis

\section{Introduction}

Gliomas comprise the majority of malignant brain tumours in adults and are characterized by a high recurrence rate and poor overall survival (1). According to the World Health Organization (WHO) guidelines, gliomas are categorized into four grades (I to IV), where low-grade gliomas include grade I and grade II, and high-grade gliomas, which are aggressive, include grade III and grade IV glioblastoma (GBM) (2). Despite the use of comprehensive treatments, including neurosurgical resection, radiotherapy and chemotherapy, the prognosis of glioma patients remains poor, especially GBM, which tends to recur and is associated with short survival time (3).

The discovery of immune checkpoints has provided novel therapeutic targets, which have brought hope, especially for brain tumour immunotherapy (4). The programmed death-1 (PD-1) protein and its ligand, programmed death ligand 1 (PD-L1), are the most intensely investigated immune checkpoints in the era of immuno-oncology. PD-1 has been reported to be expressed by activated $T$ cells and to mediate immuno-suppression (5). PD-L1 is overexpressed by tumour cells and interacts with PD-1, which triggers the anergy or apoptosis of T cells and thereby contributes to tumour immune escape and tumour progression (6). Many clinical studies have demonstrated that the expression of PD-L1 on tumour cells or in the tumour microenvironment is associated with poor clinical prognosis and can predict the progression of several types of tumours (7-9), and this molecule has become the most widely adopted indicator of tumour progression (10).

PD-L1 is expressed not only on the surface of cells but also in soluble form in the circulation, with the amount in circulation being related to the number of PD-L1-expressing cells (11). Similar to membranebinding PD-L1, soluble PD-L1 (sPD-L1) has a predictive value for cancer (12), with a high level of sPD-L1 being associated with an increased risk of tumour progression (13). Circulating soluble PD-1 (sPD-1) in the bloodstream is believed to block the PD-1/PD-L1 signalling pathway and is thus used as an indicator of immune balance (14).

Accumulating studies have characterized the expression of PD-L1 in glioma $(15,16)$. PD-L1 expression in tissue was found to be positively associ- $\mathrm{pg} / \mathrm{mL}$ ) mogu ukazati na kraće vreme preživljavanja pacijenata sa gliomom bez progresije.

Zaključak: Ova studija je pokazala da se sPD-1 i sPD-L1 mogu smatrati obećavajućim prediktivnim biomarkerima za dijagnozu i prognozu pacijenata sa gliomom.

Ključne reči: rastvorljivi programirani smrtni-1, rastvorljivi programirani smrtni ligand 1, gliom, biomarkeri, prognoza

ated with WHO grade (17) and described as a negative prognostic marker in glioma patients (18). These findings raised our interest in determining whether soluble immune checkpoints can serve as biomarkers, as do their membrane-bound forms, in gliomas.

In the present study, we addressed three hypotheses through clinical comparisons and found the following: (a) SPD-1 and sPD-L1 levels in the circulation were higher in glioma patients than in healthy controls; (b) the levels were modified by surgical resection, and (c) SPD-1 and SPD-L1 in peripheral blood have the potential to predict glioma recurrence. This report provides insight into potential biomarkers for diagnosis and prognosis in gliomas.

\section{Materials and Methods}

The study was approved by the Ethics Committee of Beijing Tiantan Hospital. Written informed consent for the procedures and publishing of data was obtained from the patients and their families. All procedures were performed after obtaining informed consent in accordance with the approved protocol.

\section{Patients and samples}

This study enrolled two independent groups of glioma patients from Beijing Tiantan Hospital who received maximal safe resection and had histologically confirmed glioma.

Patients with brain tumours who underwent magnetic resonance imaging (MRI) between January 2016 and April 2018 were selected, and blood samples were prospectively collected before their surgical resections. Seventy patients with pathologically confirmed gliomas were incorporated into the pre-operative (Pre) group. Tumour volumes were measured via T2/FLAIR brain MRI.

The Pre group included six patients with gangliogliomas (GGs), 19 with low-grade astrocytomas (LGAs), 7 with oligodendrogliomas (ODGs), 12 with anaplastic gliomas (AGs) and 26 with GBMs. According to the WHO classification, 70 glioma patients were divided into grade I $(8,11.4 \%)$, grade II $(23,32.9 \%)$, grade III $(13,18.6 \%)$ and grade IV $(26$, $37.1 \%)$. Patients were followed-up to evaluate progression by brain MRI examinations. Progression was 
defined according to the Response Assessment in Neuro-Oncology (RANO) criteria, and progressionfree survival (PFS) was defined as the date of resection to the date of progressive disease or death (19). PFS was the endpoint.

An independent cohort of 90 patients with GBM was used as the post-operative (Post) group. These patients were initially diagnosed between 2013 and 2017, and blood samples were obtained from each subject 5 to 15 days after surgery. The clinical data were extracted from medical records.

All cases were diagnosed histologically based on the 2007 WHO classification guidelines by the Department of Pathology at the Beijing Tiantan Hospital. Patients were eligible for this study if they had a newly diagnosed glioma and a complete surgical resection. None of the patients received chemotherapy, radiation or other immunotherapy.

We also analysed 20 healthy volunteers as a healthy control $(\mathrm{HC})$ group; these volunteers had no cancer and no chronic diseases and were recruited during routine periodic medical examinations.

\section{Blood sampling}

Patients' serum was obtained from residual blood samples that had been collected for other laboratory tests. To remove blood cells, serum tubes were centrifuged at 3,000 revolutions per minute for $10 \mathrm{~min}$ at room temperature. Separated serum samples were immediately stored at $-80^{\circ} \mathrm{C}$ until analysis. The repeated freezing and thawing of samples was avoided.

\section{Measurement of serum SPD-1 and SPD-L 1}

Serum levels of both sPD-1 and sPD-L1 were examined using specific enzyme-linked immunosorbent assay (ELISA) kits from Cusabio Biotech (Wuhan, China) according to the manufacturer's protocol.
Each sample was tested in duplicate. The detection limit for ELISA was $3.9 \mathrm{pg} / \mathrm{mL}$.

\section{Statistical analysis}

The variables were investigated using ShapiroWilk tests to determine whether they were normally distributed. Continuous variables were displayed as the mean \pm standard deviation (SD) or median with the minimum-maximum range. As most of the variables were not normally distributed, nonparametric methods were used for analysis. Differences in serum levels between cohorts were determined by using the Mann-Whitney or Kruskal-Wallis test. For the subanalysis of a statistically significant test, Bonferroni correction was used. Cut-off values for defining the high and low values of each variable were determined using receiver operating characteristic (ROC) analysis. PFS curves were performed using the Kaplan-Meier (K-M) method. A log-rank test was adopted to compare the survival curves. In the box plots, the horizontal lines indicate the median.

Statistical analyses were performed with SPSS (version 24.0, IBM, New York, USA). Statistical significance was defined as $p<0.05\left(^{*}\right)$ or $p<0.001\left(^{* * *}\right)$. Figures were constructed using GraphPad Prism (version 7, GraphPad Software, San Diego, California, USA).

\section{Results}

\section{Patient characteristics}

A total of 160 patients with glioma were included in the cohort study. In the Pre group, there were 70 patients representing cases of gliomas before resection. In the Post group, there were 90 glioblastoma patients whose blood samples were obtained 515 days after surgery. A total of 20 healthy volunteers were enrolled in the $\mathrm{HC}$ group. The characteristics and concentrations of sPD-1 and SPD-L1 are summarized in Table I.

Table I Baseline patient characteristics and serum levels in different groups.

\begin{tabular}{|l|c|c|c|c|}
\hline & Pre group & Post group & HC group & P \\
\hline $\mathrm{N}$ & 70 & 90 & 20 & - \\
\hline Age (year) & $40.41 \pm 16.37$ & $45.30 \pm 15.48$ & $37.65 \pm 11.81$ & 0.068 \\
\hline Sex $(\mathrm{M} / \mathrm{F})$ & $39 / 31$ & $57 / 33$ & $10 / 10$ & 0.432 \\
\hline Tumour size $\left(\mathrm{cm}^{3}\right)$ & $45.80(1.50-472.50)$ & $71.30(4.00-490.00)$ & - & 0.181 \\
\hline sPD-1 $(\mathrm{pg} / \mathrm{mL})^{\mathrm{a}}$ & $11.28(3.20-80.24)$ & $8.79(0-63.13)$ & $6.42(0-31.31)$ & $<0.001^{\mathrm{b}}$ \\
\hline sPD-L1 $(\mathrm{pg} / \mathrm{mL})^{\mathrm{a}}$ & $49.96(22.08-82.13)$ & $8.97(0-55.98)$ & $34.48(23.00-45.64)$ & $<0.001^{\mathrm{b}}$ \\
\hline
\end{tabular}

Kruskal-Wallis test

${ }^{a}$ Median (min-max)

b Statistically significant 

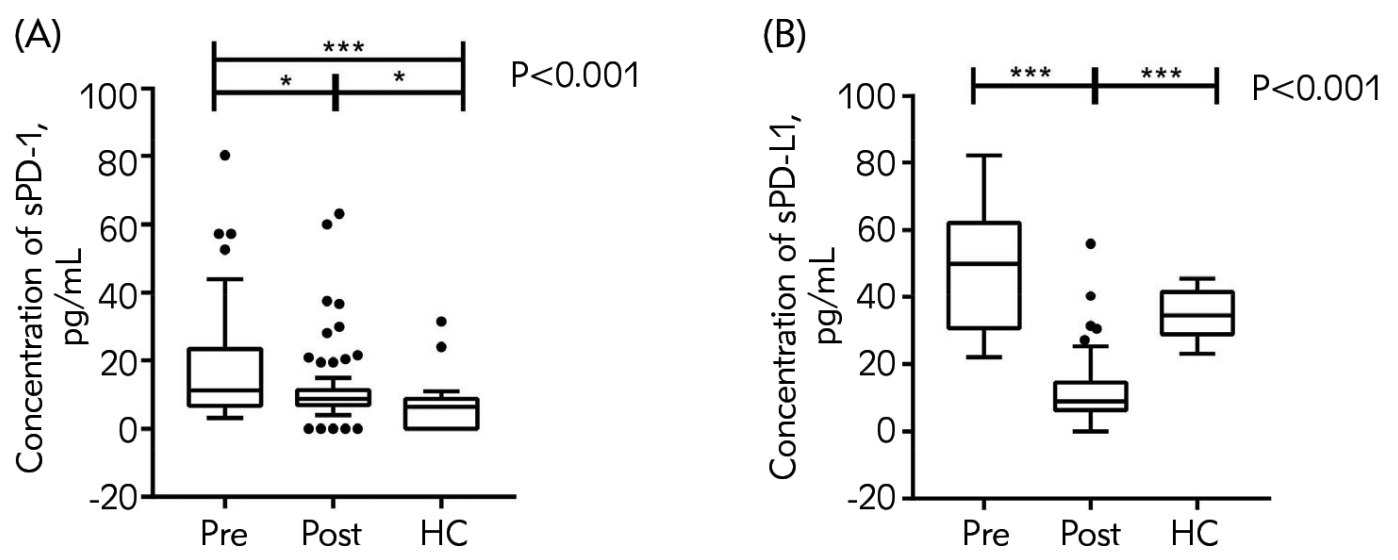

Figure 1 Serum levels of markers in glioma patients and healthy controls. (A) Serum sPD-1. (B) Serum sPD-L1.

As shown in Figure 1, no difference was found in age or sex among the three groups. The intergroup differences in the concentration medians of both SPD-1 and SPD-L1 were statistically significant $(p<0.001)$. Additionally, we found more significant levels of the soluble proteins in the serum of patients who received resections than in those who did not (Figure 1).

Serum sPD-1 levels were significantly higher in the Pre group than in the HC group $(p<0.001)$ and Post group $(p=0.050)$. Compared with the HC group, the Post group had higher median sPD-1 levels $(p=0.039)$ (Figure 1A).

The sPD-L1 levels in the Post group were significantly lower than those in the Pre group $(p<0.001)$ and HC group $(p<0.001)$. The sPD-L1 concentration did not differ significantly between the Pre and $\mathrm{HC}$ groups $(p=0.369)$ (Figure 1B).

The diagnostic value of SPD-1 and SPD-L1 in glioma

The ROC curve and area under the curve (AUC) were used to assess the ability of the soluble molecules to allow discrimination between patients and healthy subjects.

The optimal cut-off value of sPD-1 was 11.05 $\mathrm{pg} / \mathrm{mL}$, as defined by ROC curves for newly diagnosed glioma patients, with an AUC value of 0.762 (95\% confidence interval $(\mathrm{Cl})$ 0.638-0.886, $\mathrm{p}<0.001)$. The optimal cut-off value for sPD-L1 was $46.16 \mathrm{pg} / \mathrm{mL}$, with an AUC of $0.718(95 \% \mathrm{Cl} 0.616$ $0.819, \mathrm{p}=0.003$ ) (Figure 2).

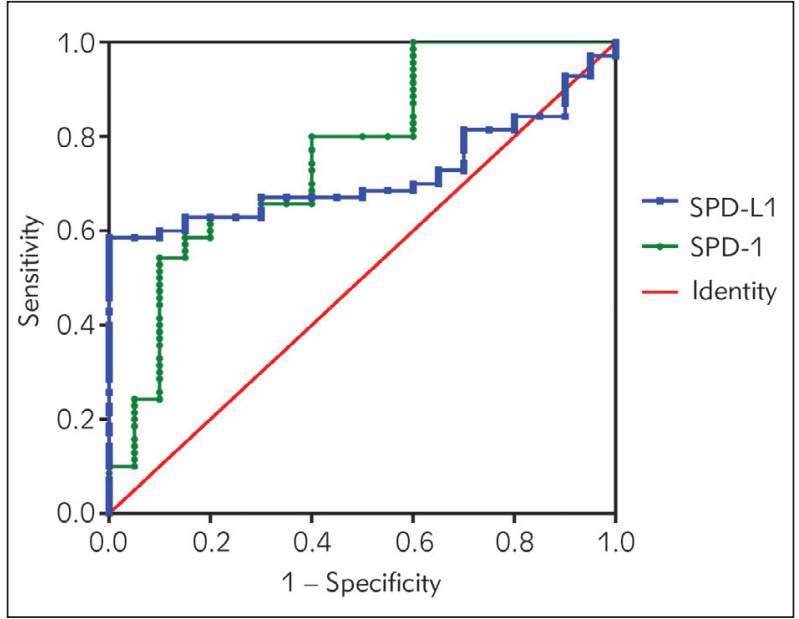

Figure 2 ROC curve analysis of serum sPD-1 and sPD-L1 concentrations in newly diagnosed glioma patients.

Correlations between serum concentrations and disease features

Clinicopathological information of all 70 patients in the Pre group was recorded. Comparisons of serum SPD-1 and SPD-L1 levels in each disease feature are shown in Table II. There were no significant differences in the levels of either soluble marker concerning sex, age, and tumour size (all $\mathrm{p}>0.05$ ).

As shown in Table II, the concentrations of sPD1 and SPD-L1 differed significantly according to grade (mild vs advanced) $(p<0.001$ and $p=0.027$, respectively). In addition, sPD-1 levels differed among histopathological types $(p<0.001)$. Although sPD-L1 level varied by pathological type, no significant difference was observed $(p=0.057)$.

As indicated in Figure 3, the concentration of sPD-1 was increased in GBM (WHO grade IV) relative to low-grade gliomas, such as ODG (grade I), LGA and ODG (grade II). Interestingly, sPD-L1 level was much higher in GBM than in the other lower-grade 
Table II Correlations between serum concentrations and disease features.

\begin{tabular}{|c|c|c|c|c|c|c|}
\hline Variable & Category & Cases & sPD-1 (pg/mL)a & $p$ value & sPD-L1 (pg/mL)a & $p$ value \\
\hline \multirow[t]{3}{*}{ Age (years) } & $\leq 18$ & 11 & 7.28 (5.27-30.11) & 0.556 & 50.06 (24.88-71.92) & 0.898 \\
\hline & $19-60$ & 47 & $11.36(3.20-57.24)$ & & 49.57 (22.08-82.13) & \\
\hline & $>60$ & 12 & $23.55(5.24-80.24)$ & & $53.98(23.24-80.82)$ & \\
\hline \multirow[t]{2}{*}{ Sex } & Male & 39 & $11.36(3.36-52.64)$ & 0.718 & $52.32(22.08-82.13)$ & 0.732 \\
\hline & female & 31 & $11.20(3.20-80.24)$ & & $49.47(22.53-80.82)$ & \\
\hline \multirow[t]{2}{*}{ Tumour size $\left(\mathrm{cm}^{3}\right)$} & 45.8 & 35 & $10.51(3.20-80.24)$ & 0.545 & $45.12(22.08-82.13)$ & 0.681 \\
\hline & $\geq 45.8$ & 35 & $14.13(4.92-44.08)$ & & $53.96(22.53-79.53)$ & \\
\hline \multirow[t]{4}{*}{ Grade (WHO) } & 1 & 8 & $6.18(3.36-15.21)$ & $0.000^{b}$ & 31.12 (25.28-59.63) & $0.027 b$ \\
\hline & II & 23 & $7.68(3.20-52.64)$ & & $43.98(22.53-73.34)$ & \\
\hline & III & 13 & $11.36(4.78-57.24)$ & & 49.57 (23.62-71.45) & \\
\hline & IV & 26 & $23.58(6.82-80.24)$ & & $59.58(22.08-82.13)$ & \\
\hline \multirow[t]{5}{*}{$\begin{array}{l}\text { Histopathological } \\
\text { type }\end{array}$} & GG & 6 & 7.34 (4.20-15.21) & $0.000^{b}$ & $31.12(25.28-59.63)$ & 0.057 \\
\hline & LGA & 19 & $6.89(3.20-57.24)$ & & $40.31(22.53-73.34)$ & \\
\hline & ODG & 7 & $8.92(4.92-14.13)$ & & $56.43(23.08-65.76)$ & \\
\hline & OG & 12 & $10.94(4.78-28.72)$ & & $47.34(23.62-62.80)$ & \\
\hline & GBM & 26 & $23.58(6.82-80.24)$ & & $57.58(22.08-82.13)$ & \\
\hline \multirow[t]{2}{*}{ Recurrence } & $(+)$ & 21 & $23.20(6.89-44.08)$ & $0.000^{b}$ & $54.00(22.08-82.13)$ & 0.198 \\
\hline & $(-)$ & 49 & $8.34(3.20-80.24)$ & & $49.57(22.53-80.82)$ & \\
\hline
\end{tabular}

Mann-Whitney $U$ test \& Kruskal-Wallis test

a Median (min-max)

b Statistically significant

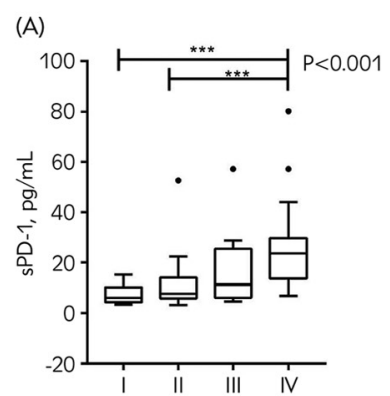

(B)

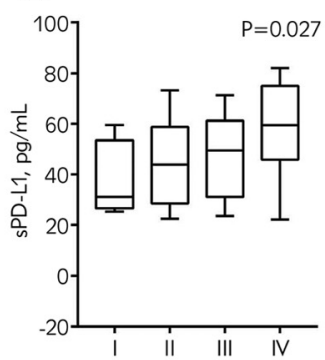

(C)

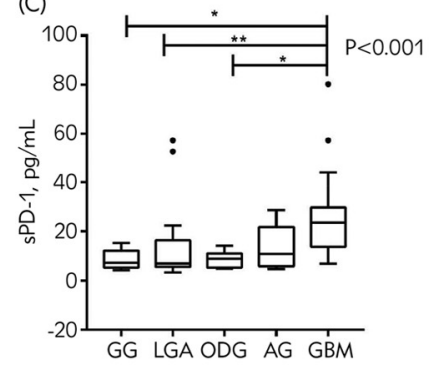

(D)

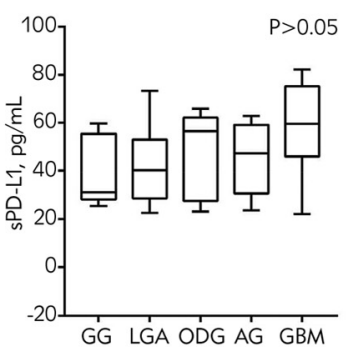

Figure 3 The diversity of serum levels in different glioma grades and different morphological types. (A \& C) Soluble PD-1. (B \& D) Soluble PD-L1.

gliomas, although the differences were not significant.

Prognostic potential of sPD-1/sPD-L1 for postsurgery glioma recurrence

At a median follow-up time of 17.0 months $(95 \% \mathrm{Cl} 17.66-21.0)$, postoperative recurrence had occurred in 21 patients at the time of data analysis.
As shown in Table II, a significant difference was observed in SPD-1 level between glioma-recurrence patients and progression-free survivors. Differences in sPD-L1 levels were not observed among the pathological types. In Figure 4, box plots of each soluble molecule are presented to the right of their corresponding ROC curves (Figure $4 C \& D$ ).

We employed ROC curve analysis to assess the ability of serum SPD-1 and SPD-L1 to predict recur- 


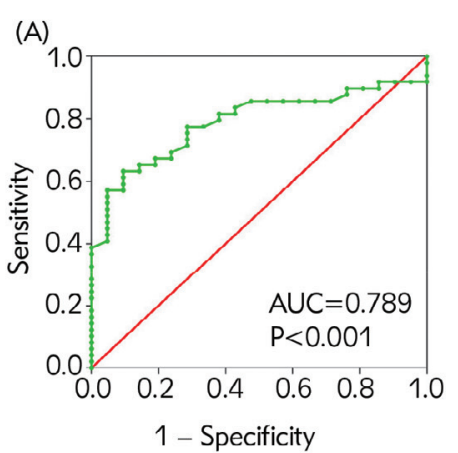

(B)

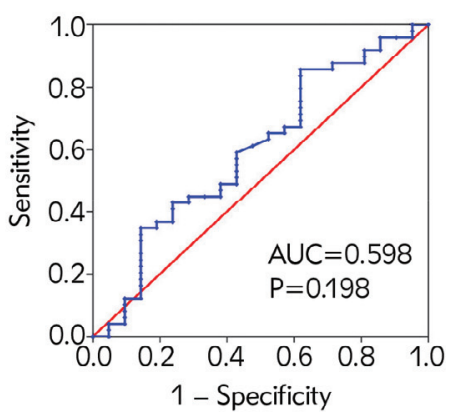

(C)

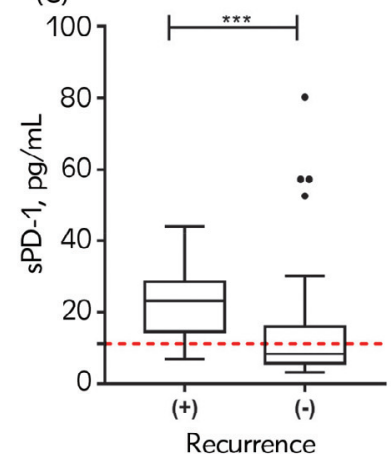

(D)

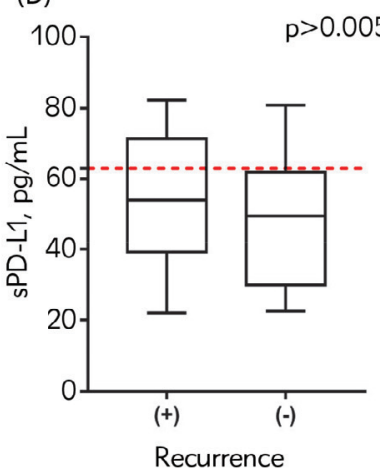

(E)

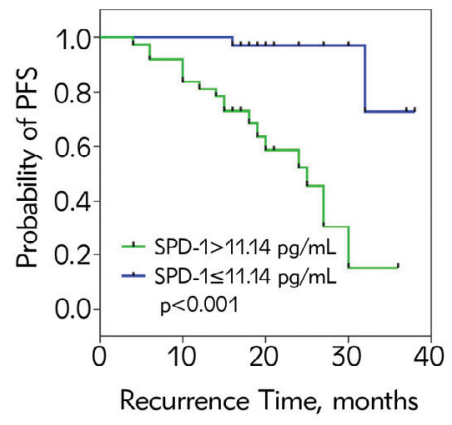

(F)

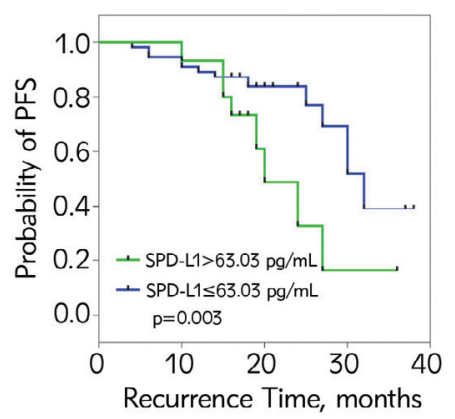

Figure 4 (A \& B) ROC curve analyses of serum sPD-1 and sPD-L1 levels for predicting glioma recurrence. (C \& D) Serum levels of each marker in patients with recurrence and progression-free survivors; the red dashed lines indicate the optimal cut-off values. (E \& F) Kaplan-Meier analysis of PFS in patients with high and low serum levels of sPD-1 and sPD-L1.

rence. As shown in Figure $3 A \& B$, the optimal cut-off value of sPD-1 was $11.14 \mathrm{pg} / \mathrm{mL}$, as defined by ROC curves for tumour recurrence, with an AUC value of 0.789 (95\% Cl 0.683-0.894, p<0.001). The optimal cut-off value for sPD-L1 was $63.03 \mathrm{pg} / \mathrm{mL}$, with an AUC value of $0.598(95 \% \mathrm{Cl}$ 0.448-0.748, $p=0.198)$.

The patients were classified as having low or high levels of each marker by using the optimal thresholds mentioned above. For both sPD-1 and sPD-L1, we noted markedly significant differences in PFS between the high- and low-level groups (Figure $4 E \& F)$.

Kaplan-Meyer analyses indicated that high sPD1 concentrations (>11.14 pg/mL) predict shorter PFS times, with a median of 25.0 months for glioma patients (log-rank $p<0.001$ ) (Figure 4E).

Similarly, patients with a high level of sPD-L1 (>63.03 pg/mL) have a poorer PFS rate than patients with a low level of sPD-L1 (median progression time with high vs. low: 20.0 months vs 32.0 months; log-rank $\mathrm{p}=0.030$ ) (Figure 4F).

\section{Discussion}

With the remarkable clinical success of immune checkpoint inhibitors in several refractory tumours, PD-1 and its ligand PD-L1 have generated increasing interest in exploring potential treatment targets and promising biomarkers in glioma therapies $(20,21)$. In the present study, we characterized the expression of soluble PD-1 and PD-L1 in the serum of newly diagnosed glioma patients and investigated the potential predictive roles of these markers.

Prior studies indicated that the secretion of sPD1 and SPD-L1 in sera might be relevant to the corresponding membrane-bound molecules on tumour cells or immune cells (22). Therefore, we hypothesized that higher levels of these soluble molecules might be detected in the blood of tumour patients than in the blood of healthy individuals. As expected, elevated sPD-1 and sPD-L1 levels were detected in the pre-operative sera of 70 glioma patients relative to the levels in healthy controls. In addition, we observed markedly decreased circulating levels in 90 GBM patients after tumour resections. The preliminary results suggested that the decrease in concentrations might be related to the removal of the tumour. We performed a ROC curve analysis to iden- 
tify the optimal cut-off value for glioma diagnosis. The AUC of sPD-1 level was considered adequate for diagnosing gliomas and was similar to that of sPD-L1 (0.762 and 0.718, respectively). These results support sPD-1 and sPD-L1 as potential diagnostic markers.

Recent studies have shown that PD-1 and PDL1 are highly expressed in malignant gliomas and that their expression is closely associated with malignant grades and adverse outcomes (23, 24). Consistent with these studies, our data revealed trends of higher serum sPD-1 and SPD-L1 levels with increasing malignancy grade. Notably, we found that patients with GBM showed markedly higher serum levels of sPD-1/sPD-L1 than did patients with lowergrade gliomas. Some studies have shown that high levels of soluble PD-1 and PD-L1 are associated with worse clinical outcomes in several types of tumours $(25,26)$; moreover, researchers have speculated that the expression of these markers in peripheral blood reflects the immune environment and have shown them to be highly correlated with malignant neoplasm behaviour (7). Since gliomas are the most aggressive form of brain neoplasms, with a high recurrence rate, we speculate that high serum levels of sPD-1/PD-L1 in gliomas might have the potential to predict tumour recurrence and progression.

ROC curves were constructed to assess the efficacy of sPD-1 and SPD-L1 in predicting glioma recurrence. Although SPD-L1 failed to predict tumour recurrence $(p>0.05), K-M$ analysis demonstrated that higher levels of sPD-L1 (higher than the threshold level determined from the ROC curves) were correlated with shorter PFS. Additionally, serum sPD-1 levels demonstrated good prognostic performance for PFS as revealed by ROC curve and K-M analyses. Therefore, circulating immune checkpoint parameters might serve as alternative markers for monitoring tumour aggressiveness in the post-surgery management of glioma.

However, the differences in circulating SPD-L1 level among histologic types in our research were not significant $(p>0.05)$. In addition, we found that tumour size was not parallel to the serum level of

\section{References}

1. Wang $Y$, Jiang T. Understanding high grade glioma: molecular mechanism, therapy and comprehensive management. Cancer letters 2013; 331(2): 139-46.

2. Louis DN, Ohgaki H, Wiestler OD, Cavenee WK, Burger PC, Jouvet A et al. The 2007 WHO Classification of Tumours of the Central Nervous System 2007; 114(2): 97-109.

3. Stupp R, Taillibert S, Kanner A, Read W, Steinberg D, Lhermitte $B$ et al. Effect of Tumor-Treating Fields Plus Maintenance Temozolomide vs Maintenance Temo-
SPD-1 or SPD-L1 before resection, potentially due to the protective blood barrier; thus, the concentrations of these molecules in sera do not reflect tumour size. Another potential reason for the lack of observed differences in circulating SPD-L1 level among histologic types is that SPD-1 and SPD-L1 are not exclusive to tumour cells (27) and are released by diverse cell populations through different mechanisms, including intrinsic splicing $(13,28)$ and the cleavage of membrane-bound counterparts (11).

Although our study detected two potential markers for diagnosing and predicting recurrence in glioma patients, there are some limitations to the study. First, the composition of grades and the small number of patients limited our ability to detect and describe the predictive power of these soluble markers. Second, the clinical data of glioma patients lacked molecular classification in our hospital. As molecular classification paves the way for more precise medicine for gliomas (29), further research should attempt to investigate the associations of molecular markers with circulating sPD-1/PD-L1 levels in the peripheral blood of glioma patients.

\section{Conclusions}

This study found elevated levels of sPD-1 and SPD-L1 in the serum of glioma patients relative to the levels in healthy patients, and these levels might be modified by tumour removal. In addition, higher serum sPD-1/sPD-L1 levels showed a predictive capacity for diagnosis and progression. This study provides clinical data that can inform future studies of the potential of soluble PD-1 and PD-L1 as biomarkers in malignant brain tumours.

Acknowledgements. This work was supported by the National Science and Technology Major Project of China (2018ZX10307415-003).

\section{Conflict of interest statement}

The authors declare that they have no conflict of interest.

zolomide Alone on Survival in Patients With Glioblastoma: A Randomized Clinical Trial. Jama 2017; 318(23): 2306-16.

4. Reiss SN, Yerram P, Modelevsky L, Grommes C. Retrospective review of safety and efficacy of programmed cell death-1 inhibitors in refractory high grade gliomas. J Immunother Cancer 2017; 5(1): 99.

5. Boussiotis VA, Chatterjee P, Li L. Biochemical signaling of PD-1 on $T$ cells and its functional implications. Cancer J 2014; 20(4): 265-71. 
6. Ribas A. Adaptive Immune Resistance: How Cancer Protects from Immune Attack. Cancer Discov 2015; 5(9): 915-9.

7. Amatatsu M, Arigami T, Uenosono $Y$, Yanagita $S$, Uchikado Y, Kijima $Y$ et al. Programmed death-ligand 1 is a promising blood marker for predicting tumor progression and prognosis in patients with gastric cancer. Cancer science 2018; 109(3): 814-20.

8. Xu J, Han X, Liu C, Gao N, Zhao J, Zhang X et al. PDL1 expression in pleural effusions of pulmonary adenocarcinoma and survival prediction: a controlled study by pleural biopsy. Scientific reports 2018; 8(1): 11206.

9. Takada K, Toyokawa G, Shoji F, Okamoto T, Maehara Y. The Significance of the PD-L1 Expression in NonSmall-Cell Lung Cancer: Trenchant Double Swords as Predictive and Prognostic Markers. Clin Lung Cancer 2018; 19(2): 120-9.

10. Yi M, Jiao D, Xu H, Liu Q, Zhao W, Han X et al Biomarkers for predicting efficacy of PD-1/PD-L1 inhibitors. Molecular cancer 2018; 17(1): 129.

11. Chen $Y$, Wang $Q$, Shi B, Xu $P, H u$ Z, Bai $L$ et al. Development of a sandwich ELISA for evaluating soluble PD-L1 (CD274) in human sera of different ages as well as supernatants of PD-L1+ cell lines. Cytokine 2011; 56(2): 231-8.

12. Shigemori T, Toiyama $Y$, Okugawa $Y$, Yamamoto A, Yin C, Narumi A et al. Soluble PD-L1 Expression in Circulation as a Predictive Marker for Recurrence and Prognosis in Gastric Cancer: Direct Comparison of the Clinical Burden Between Tissue and Serum PD-L1 Expression. Ann Surg Oncol 2019; 26(3): 876-83.

13. Zhou J, Mahoney KM, Giobbie-Hurder A, Zhao F, Lee S, Liao X et al. Soluble PD-L1 as a Biomarker in Malignant Melanoma Treated with Checkpoint Blockade. Cancer Immunology Research 2017; 5(6): 480-92.

14. Dai S, Jia R, Zhang X, Fang Q, Huang L. The PD-1/PDLs pathway and autoimmune diseases. Cellular immunology 2014; 290(1): 72-9.

15. Berghoff AS, Kiesel B, Widhalm G, Rajky O, Ricken G, Wohrer $A$ et al. Programmed death ligand 1 expression and tumor-infiltrating lymphocytes in glioblastoma. Neuro-Oncology 2015; 17(8): 1064-75.

16. Nduom EK, Wei J, Yaghi NK, Huang N, Kong LY, Gabrusiewicz $\mathrm{K}$ et al. PD-L1 expression and prognostic impact in glioblastoma. Neuro-Oncology 2016; 18(2): 195-205.

17. Wang Z, Zhang C, Liu X, Wang Z, Sun L, Li G et al. Molecular and clinical characterization of PD-L1 expression at transcriptional level via 976 samples of brain glioma. Oncoimmunology 2016; 5(11): e1196310.

18. Pratt D, Dominah G, Lobel G, Obungu A, Lynes J, Sanchez $\vee$ et al. Programmed Death Ligand 1 Is a Negative Prognostic Marker in Recurrent Isocitrate Dehydrogenase-Wildtype Glioblastoma. Neurosurgery 2018.
19. van den Bent MJ, Wefel JS, Schiff D, Taphoorn MJ, Jaeckle $K$, Junck $L$ et al. Response assessment in neurooncology (a report of the RANO group): assessment of outcome in trials of diffuse low-grade gliomas. Lancet Oncol 2011; 12(6): 583-93.

20. Omuro A, Vlahovic G, Lim M, Sahebjam S, Baehring J, Cloughesy $T$ et al. Nivolumab with or without ipilimumab in patients with recurrent glioblastoma: results from exploratory phase I cohorts of CheckMate 143. NeuroOncology 2018; 20(5): 674-86.

21. Reardon DA, Kim TM, Frenel JS, Santoro A, Lopez J, Subramaniam DS et al. Results of the Phase Ib Keynote028 Multi-Cohort Trial of Pembrolizumab Monotherapy in Patients with Recurrent Pd-L1-Positive Glioblastoma Multiforme (Gbm). Neuro Oncol 2016; 18: 25-6.

22. Zhu X, Lang J. Soluble PD-1 and PD-L1: predictive and prognostic significance in cancer. Oncotarget 2017 8(57): 97671-82. doi:10.18632/oncotarget.18311.

23. Garber ST, Hashimoto Y, Weathers SP, Xiu J, Gatalica Z, Verhaak RG et al. Immune checkpoint blockade as a potential therapeutic target: surveying CNS malignancies. Neuro-Oncology 2016; 18(10): 1357-66.

24. Liu S, Wang Z, Wang Y, Fan X, Zhang C, Ma W et al. PD-1 related transcriptome profile and clinical outcome in diffuse gliomas. Oncoimmunology 2018; 7(2): e1382792.

25. Ha H, Bang JH, Nam AR, Park JE, Jin MH, Bang YJ et al. Dynamics of Soluble Programmed Death-Ligand 1 (sPDL1) during Chemotherapy and Its Prognostic Implications in Cancer Patients: Biomarker Development in Immuno-oncology. Cancer Res Treat 2019; 51(2): 832-40.

26. Chang B, Huang T, Wei H, Shen L, Zhu D, He W et al. The correlation and prognostic value of serum levels of soluble programmed death protein 1 (sPD-1) and soluble programmed death-ligand 1 (sPD-L1) in patients with hepatocellular carcinoma. Cancer Immunology, Immunotherapy: CII 2019; 68(3): 353-63.

27. Mahoney KM, Shukla SA, Patsoukis N, Chaudhri A, Browne EP, Arazi A et al. A secreted PD-L1 splice variant that covalently dimerizes and mediates immunosuppression. Cancer Immunology, Immunotherapy: CII 2019; 68(3): 421-32.

28. Nielsen C, Ohm-Laursen L, Barington T, Husby S, Lillevang ST. Alternative splice variants of the human PD1 gene. Cell Immunol 2005; 235(2): 109-16.

29. Reifenberger G, Wirsching H-G, Knobbe-Thomsen CB, Weller M. Advances in the molecular genetics of gliomas - implications for classification and therapy. Nature Reviews Clinical Oncology 2016; 14: 434. 